\title{
GOVERNMENTAL REPRESSION AND LIKELIHOOD OF CIVIL WAR ONSET: WORLD ANALYSIS, 1981-1997*
}

\author{
Represión gubernamental y probabilidad del comienzo de una guerra \\ civil: análisis mundial, 1981-1997
}

\author{
ARTUR ZIMERMAN \\ Universidad: Universidade de São Paulo (USP) \\ HÉLIO RICARDO DO COUTO ALVES \\ Universidad: Fundação Universidade Federal do Rio Grande (FURG)
}

\begin{abstract}
The purpose of this paper is to investigate governmental repression combined with the type of regime that might determine a civil war. As a rule, scholars have not considered both variables in one quantitative model, in a systematic fashion. No empirical work employing political philosophy approaches can be found among the current quantitative literature on civil war. Therefore, this paper fills the gap, by grounding our work on a more robust theory, complementing the originally data-driven pieces. Three different hypotheses are tested and the findings indicate that poor countries with hybrid regimes and a high level of governmental repression are more likely to become involved in civil wars than countries with democratic or autocratic regimes. This paper can work as a contribution to the failed states discussion.
\end{abstract}

Key words: civil war, political regimes, governmental repression, income per capita.

\section{RESUMEN}

El propósito de este artículo es investigar la represión gubernamental combinada con el tipo de régimen como posible determinante del comienzo de una guerra civil. En general, los académicos no han considerado ambas variables en un único modelo, tal y como nosotros lo hacemos de manera cuantitativa y sistemática. En la literatura cuantitativa sobre las guerras civiles no existen trabajos empíricos que hayan empleado enfoques de filosofía política. En consecuencia, tratamos de llenar esta brecha basando nuestro trabajo en una teoría más robusta y complementando las bases de datos tradicionalmente utilizadas. Tres diferentes hipótesis han sido testeadas y los hallazgos indican que países pobres con regímenes híbridos y altos niveles de represión gubernamental son más propensos a verse envueltos en guerras civiles que países con regímenes democráticos y autocráticos. Este trabajo pretende ser una contribución a la discusión sobre los estados fallidos.

Palabras clave: guerra civil, regímenes políticos, represión gubernamental, ingreso per cápita.

* We have been extremely fortunate to count on excellent and careful observations from the anonymous reviewers and we would like to thank also to all the colleagues from Universidade de São Paulo and Yale University who made a contribution to this paper. A special acknowledgment is given to David Altman, who was emphatic about the quality of this work and insist for the improvements we have made. CNPq, CAPES and FAPESP gave financial support for this research. A previous version of this piece was presented on the International Studies Association (ISA) at San Diego, in March 2006. 


\section{INTRODUCTION}

This paper focuses on governmental repression and whether it may -or not- be a determinant for the onset of a civil war. We begin by defining the boundaries of citizens' obedience/disobedience to governments and/or the political system. Afterwards, we try to find out when and under which circumstances part of the population may continue to cooperate with the state or a new political structure capable of meeting citizens' needs more effectively should be created once all outcomes are exhausted.

It is necessary to study the effect of governmental repression on civil insurgency. We must consider whether the people's level of indignation about repression is so high that they decide to take action and start a civil war; or, as opposed to this, their fear of being even more victimized by repression is so strong that they take no action against the state.

Considering both of the above-mentioned effects, the following hypotheses will be tested:

1) Different types of political regimes have a diverse effect on the civil war onset.

2) Civil wars are more likely to occur in an hybrid regime with a high level of repression than in a democratic or an autocratic regime.

3) The lower the average income per capita, the higher the risk of civil war.

We will test the repression level in association with the various types of regimes to indicate the likelihood of civil war onset in the period 1981-1997.

\section{CO-OPERATE OR BREAK WITH THE STATE?}

Laws are to be obeyed. In a democratic society, they are "the rules of the game" previously accepted by all players. Whereas complying with the law is part of the institutional fair play of living in a society, it is not a mandatory obligation and may be disregarded under certain circumstances. Laws can -and must- be compared with some higher moral standards. As a result, the decision of complying with them or not may require judgment on a case-to-case basis.

Our moral standards may be a fair enough reason for not complying with the law, and our "malfeasance" may not be punished in some cases. In fact, this kind of "automatic response model" which establishes that "each breach must be punished accordingly" is not realistic. Not infrequently the fate of people who deliberately breach the law is left to the discretion of judges, prosecutors, and the State itself.

Obviously people break the law for various reasons such as greed, selfishness, cruelty, etc. These non-moral motivations are not addressed in theories of civil disobedience or political protests. And this section does not deal with them, either. Instead, it focuses on the legitimacy of political manifestations for the most different reasons, including civil disobedience, and on how a constitutionally democratic government should react to them. 
In her well-known essay on political obligation, Hanna Pitkin highlights four aspects of this issue: the limits of obligation, the locus of sovereignty, the difference between legitimate authority and mere coercion, and the justification of obligation (Pitkin, 1965: 990).

Among these four subject matters outlined, our interest is to consider the first one. In other words, when we are bound to obey a political authority and when we are not. Such problem primarily emerges in democratic regimes, where the legitimacy of the laws is supposed. In countries ruled by authoritarian governments, rather than being grounded on moral values, obedience arises from force and fear.

Most researchers regard political obligations as essential components of any modern society. Political allegiance would therefore be the duty of every citizen, i.e., all individuals must subject themselves to legitimate political authorities and laws, even if they are not of their liking or meet their immediate self-interests.

Almost every moral philosopher and political theorist believes that at least a few moral principles are necessary to sustain citizens' political obligation. John Rawls, for example, states, "as requiring no argument that there is, at least in a society such as ours, a moral obligation to obey the law" (Rawls, 1964: 117). But Rawls believes that moral obligation rests on a moral principle, such as "a special case of the prima facie duty of fair play" (Ibid.), and changes this argument at a later moment to imply some kind of natural duty "to support and further just institutions" (Rawls, 1971: 334).

Moral principles that support political obligation vary in nature. According to a number of recent works on normative political theory, these moral principles include fairness (Klosko, 1992), natural duty (Waldron, 1993), consent (Murphy, 1997), and community obligations (Dworkin, 1986), among others. Whereas all of theses principles support political obligation, they envisage the possibility of not complying with it.

Rawls, for instance, states that "if a social or religious group reasonably (not irrationally) and correctly supposes that a permanent majority, or majority coalition, has deliberately set out to undercut its basis and that there is no chance of successful constitutional resistance, then the obligation to obey that particular law (and perhaps other laws more generally) ceases." (Rawls, 1964: 126). Also, when obedience is sustained by the notion of duty, the odds are that "permanent minorities that have suffered from injustice for many years" (Rawls, 1971: 355) they would find it very difficult to put it into practice.

However, this does not mean that individuals should lead their lives by the principle of individualist utilitarianism. If this happens, there can be no authority at all, as the notion of political obligation only makes sense if individuals do not follow just those laws that meet their short- and long-term self-interests (Pitkin, 1965: 992).

The possibility of breaching some laws should be grounded on moral ethics values, which also encompass the importance of political obligation. Those who practice acts of disobedience in democratic regimes usually perceive the system as a reasonably fair society. Their aim is to request limited reforms and not a radical overthrow of the regime. In this sense, the purpose of civil disobedience is to draw the attention to certain political 
problems or unfair laws (see Lyons, 1998: 32-34, for a skeptical position which limits the moral dissent of the disobeyers to only one part of the political system).

For Rawls, civil disobedience is "a nonviolent, conscientious yet political act contrary to law usually done with the aim of bringing about a change in the law or policies of the government", which, additionally, "addresses the sense of justice of the majority of the community" (Rawls, 1971: 364). Thus, civil disobedience does not only reject the law, but also engages in a dialogue with the State and its citizens.

Therefore, civil disobedience goes hand in hand with political obligations, being neither as radical as the armed insurgency that seeks to overthrow the established authorities nor as gentle as a simple public discordance with the promulgated law. Moreover, as there is no intention of breaking with the regime or of constitutionally reorganizing the state, it does not involve those who fundamentally defy an authority. They accept the legitimacy of the government or the community and act to have civil duties rather than defying them.

Thus, according to Dworkin, civil disobedience has a particularly interesting feature. Discordance with the legitimacy of a certain law is not founded on morality; nor is it a struggle between the virtuous and the wicked. From a theoretical point of view, it would be trivial if the divergence of this type always represented a confrontation between superior morality positions and others incapable of, for example, perceiving the injustice of their position.

Dworkin therefore proposes that civil disobedience is founded on a threefold basis: (a) integrity, (b) justice, and (c) a specific political issue or law. Examples of the first case are a pacifist who is recruited to fight a war, or a religious person who is forced to act against his or her beliefs. In the second case, the reason is different. It may be, for example, political and legal systems that systematically discriminate against specific groups of people. In the third case it is related to a law which, according to the minority who fights it, may result in serious problems to the majority or a minority of people. In this case, the purpose is not to force the majority to act fairly, but to make them 'come back to reason'. Moreover, the first two cases would involve questions of principles, as opposed to the third.

In regarding the phenomenon of civil disobedience from the standpoint of those who practice it, two causes are possible. The first is the impossibility of solving a specific problem after having turned to all institutional resources available for this purpose. The second -a consequentialist clause- is when a "wrongdoer" realizes that complying with the law may be a lot more harmful than breaching it (especially when a law is considered to be unfair).

These two clauses, however, may be hard to implement. The first implies that an individual should accept the consequences of a law until a constitutional remedy for reversing its effects is found -regardless of how seriously this temporary acceptance hurts the person's moral principles. As for the second case, although it may not be as likely, there still is a possibility that the principles in question have precedence over the consequential analyses. However, this type of civil disobedience cannot justify violence, as practicing an act of 
violence in the name of conscience makes no sense at all, especially considering that it may harm supposedly innocent people.

According to Dworkin, before practicing acts of civil disobedience, people should exhaust all normal political processes and make sure there is no more chance of succeeding. This can also support the consequentialist clause, as civil disobedience would not exist if an act could, for example, advance the policy in question. It thus seems that our bottom line is to determine when to consider that all institutional resources have been exhausted, making room for civil disobedience. This is particularly important when the political system in question is biased (the representative system is distorted, for example), and institutional reversion may be impossible under it. An example of this is the legal system that discriminated against Afro-American citizens before the Civil Rights Movement, whereby "the rule of law was a false promise" (Lyons, 1998: 39). On the other hand, when considering the possibility of a reversion from a formal standpoint -even when it seems unlikely- there would hardly be any possibility of insurgency.

Another important difference between these two types of civil disobedience is that civil disobedience based on integrity is defensive, as the sole intention in this case is to avoid individuals' having to act against their beliefs. Disobedience based on justice, in turn, is strategic and its purpose is to change the state of things that might create a situation of injustice for the largest portion of the population (Dworkin, 1985: 109). In the latter case, we may employ either a persuasive or a non-persuasive strategy when attempting to reverse the state of affairs. The first strategy consists in changing the opinion of the majority drawing attention to the injustice in question. The second consists of practicing acts politically costly to those who support the status quo.

In Dworkin's view, persuasive strategies have some advantages over the non-persuasive ones. When trying to convince the majority of their mistake, individuals submit themselves to the very principles of the majority. Non-persuasive strategies are more problematic. In a way, they represent an exception to the rule of the majority with the risk of developing paternalistic features. In this sense, before applying the non-persuasive strategies, many requirements should be met not to fail as a result, for example, of possible inefficiency or counter productiveness of the persuasive techniques (Dworkin, 1985: 110).

If, from the point of view of dissenters, civil disobedience functions as an instrument of political interest, how should the government or the majority respond to it? If civil disobedience and political protests are considered as legitimate elements of a democratic society, governments should always accept-and not prosecute- dissenters. "Society 'cannot endure' if it tolerates all disobedience; it does not follow, however, nor is there evidence, that it will collapse if it tolerates some" (Dworkin, 1977: 206).

John Rawls also affirms that civil disobedience can be "one of the stabilizing devices of a constitutional system, although by definition an illegal one" (Rawls, 1971: 383). A government must tolerate non-violent political protests -practiced in their most notorious and radical form as civil disobedience- when dissenters act in good will, appealing to the sense of justice of the community. The accommodation of conflicts takes place when government, judges and the civil society respond to this appeal deciding not to prosecute the dissenters and making the option to change the law in favor of the society's needs. 
In this first theoretical part, we tried to divert from the mainstream quantitative literature on civil war and, therefore, we have adopted a different and more robust theoretical perspective. By doing so, we expect to be able to envisage the motives of a rupture between an organized (armed) group and the State and the circumstances under which it occurs. A government might cope with some opposition instead of repression. If governmental repression leaves no room for dissidence, then some open conflict could erase (even civil wars).

The more recent works on civil war focus mostly on data rather than theory. As a result they lack theoretical coherence. As we know, scientific literature has to stand on the tripod of theory, data, and the consistency between these two arms. Therefore, the quantitative literature on civil war should be backed by the concepts of other fields of knowledge such as political philosophy and political science, among others.

\section{GOVERNMENTAL REPRESSION AND ITS EFFECTS}

How should the state respond to civil disobedience? As a rule, it is either thought that there should be no punishment at all, or, as opposed to this idea, that laws must be obeyed regardless of the circumstances. In practice, immediate punishment is not applied every time the law is broken. Even conservative magistrates accept the notion that the authorities have to decide whether or not to punish certain actions.

The actions of a government whose legitimacy is at risk shape its future engagements with dissident groups. It may try to establish some kind of dialogue with them, or simply be repressive and close all channels of participation at once. The oppositionist groups are then left with two possible counter-reactions. They will either decide to drop their demands or take a radical step towards violence.

If the State decides to close the participation channels, the oppositionist groups may choose to engage into an armed conflict. And, in this case, the State will most likely use repression to eradicate the opposition.

The literature that discusses the efficacy of repression on the part of the government is somewhat controversial. Whilst some argue that repression blocks civil disobedience and defeats opposition, others say that it strengthens the latter party.

Brockett, for example, studied five countries in Central America (El Salvador, Nicaragua, Guatemala, Costa Rica, and Honduras). He concluded that Costa Rica and Honduras are repression-free, which makes these countries less vulnerable to conflict than the other three (Brocket, 1991: 269).

As per Boix's analyses (2004), if repression is overly costly (training, military equipment, personnel), the rich accept a democratic constitution -and in a democracy the poor do not want to engage in political violence. However, when the cost of repression is low, the level of repression is high and there is hardly any chance for opposition groups to survive.

States with very repressive structures such as death squads may outrage the population, and thus contribute to rebellion (Prosterman, 1976: 9). However, it is not easy to rebel 
in an authoritarian atmosphere, as potential rebels weigh the benefits of a direct confrontation.

For Scott, the risks of a rebellion are proportional to the coercitive power of the State (1976: 196). He mentions the example of South-West Asia, affirming that the reason that the population did not rebel against the government was not that landlords and the State itself did not exploit them, but the dangers posed by potential rebels. In that case, the memory of past repressions is one of the central explanations for the inexistence of insurrections (Scott, 1976: 226-7).

Having investigated Peru and El Salvador, Mason, however, argues that the repression exercised by the state against peaceful demonstrations generated violent uprisings. Should the state have engaged into dialogue, especially with those who did not benefit from the land reform in Peru and El Salvador, there would have been nor rebellion or civil war (Mason, 1998: 201).

Govern repression does not arise from a single factor, but from a combination of factors, some of which may be determining, such as the political components. An example of how these political elements contribute to the appearance of government repression is whether the political foundation of a State is solid or fragile and, consequently, if its regime is stable or shaky. It is not our intent to disaggregate ethnic and revolutionary wars in this paper, as some authors do (as Sambanis, 2001; Fearon and Laitin, 2001; Montalvo and ReynalQuerrol, 2005), but it can make a difference, in spite of other authors (as Collier et alli., 2003) affirm that civil wars break for economic, not ethnic reasons.

Political regimes vary in structure depending on the level of political inclusiveness of their systems. According to Reynal-Querrol (2002), the most important political cause of ideological civil wars is a presidential system with a low level of democracy, which also explains the high incidence of civil wars in Latin American countries.

Centralized political power also instigates collective violence. According to Rummel (1997), when the political power is centralized, non-democratic, and highly dependent upon the affiliation to social groups (racial, ethnic, or religious), collective violence is very likely to occur.

Based on statistical analyses, this paper will seek to clarify whether under certain conditions repression leads to civil war or prevents it from breaking out. All variables mentioned by the other authors will be considered, such political regimes, inclusiveness of the system, and centralization of the political power, among others. However, just those variables that can be reliably measured will be taken into consideration. As for the others, more quantitative research must be conducted on these factors and their results must be made available for collection before they can be regarded for this purpose.

While the previous section highlighted the civil disobedience theory, this part discusses the quantitative literature on civil wars, showing the direction to which both types are headed. And it is important to note that the first (political philosophy theory, not usually brought to this subject) is complementary to the second, which is data-driven. As of this point, we will first develop our hypotheses to then explain the data used in our statistical analyses. 


\section{HYPOTHESES}

Taken in isolation, State repression does not necessarily lead to civil war. For a civil war to break out, repression must be combined with the type of regime of a country. However, we should not be tempted to automatically assume that a democratic regime does not repress dissidents and an autocratic regime does.

We do not intend to tie the level of repression to the type of regime. Regimes cannot be statistically assessed because the levels of repression vary, depending on the political and economic circumstances. They will be analyzed in temporal series, which may change periodically, independently of the type of regime.

Another difficulty would be to regard regimes in a dichotomous manner. Ignoring nondemocratic or non-autocratic regimes can be considered a methodological flaw. Between these two types of regimes, there are the so-called 'hybrid regimes', which are 'something with mixed origin or composition ${ }^{* * *}$. These regimes may be found in non-consolidated democracies, semi-democracies and semi-autocracies, among others. This group is better specified in the data section.

Consolidated ('full') democracies have channels for citizens to express their grievances. If a large portion of the population is dissatisfied with the government, they may always get rid of it by choosing other leaders in the following elections. The rotation of political power is very helpful in 'maintaining peace', as dissidents can democratically compete for political posts. In an autocracy there is no room or freedom to protest or organize rebellions. Transformation through violence is only possible under hybrid regimes (Hegre et al., 2001), which allow some freedom because of the limited repression. The combination of these two elements may give rise to civil war (as shown below).

\section{DATA}

The dependent variable -ONSET- , used separately indicates onset of civil war or the first year of this event. What it does depict is the outbreak of civil war through state repression - not its duration or the post-conflict. Developed by Fearon and Laitin (2001), this variable is not very different from those variables elaborated, for a similar purpose, by other researchers such as Doyle and Sambanis (2000), Sarkees (2000) in the Correlates of War, and Gleditsch et al. (2002) in Uppsala Conflict Data Program.

Our analysis only takes into account the data referring to the period between 1981 and 1997. Wars that started before and continued throughout this period are not considered. However, civil wars that started and continued throughout these years are included.

The unity of analysis is country/year with time-series; therefore, there may have been changes during the period investigated. These countries had more than one million inhabitants either at the beginning of the period (1981) or after their independence (ex.

** According to The American Dictionary Heritage, 2000. 
Figure 1: Civil war as a consequence of state repression and regime type.

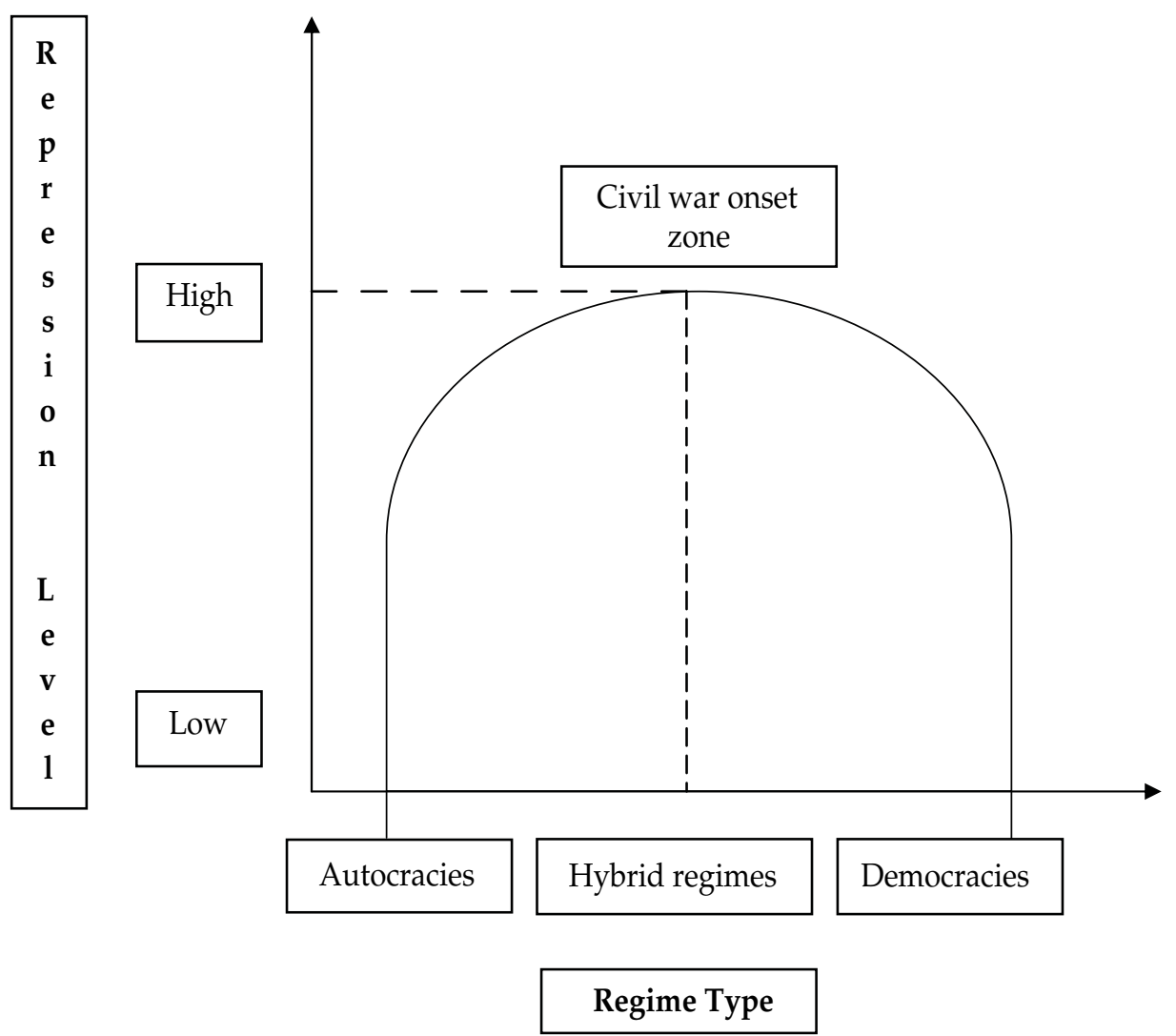

Thus, figure 1 shows that:

(1) In hybrid regimes with high levels of repression civil wars are more likely to occur.

(2) In democratic and autocratic regimes, the risk that a civil war will break out is reduced.

Hence, more political rights and civil freedom decrease the risk of civil war;

The chart below shows that the higher the country's average income per capita in a given country, the lower the chance of a civil war onset. In the last income quartile, there are no civil wars at all, while in the three first quartiles the incidence of civil war decreases in an inverse proportion to the increase in average income per capita.

(3) In rich states, in general, there are no civil wars. 
Chart 1: Income per capita (by quartiles) and the civil war onset

\begin{tabular}{c|r|r|r|r|r}
\hline \multirow{2}{*}{ Onset } & \multicolumn{3}{|c|}{ Income per capita (GDPEN) } & \multirow{2}{*}{ Total } \\
\cline { 2 - 5 } & 1 & 2 & 3 & 4 & \\
\hline 0 & 486 & 505 & 525 & 563 & 2079 \\
1 & 18 & 13 & 9 & 0 & 40 \\
Total & 504 & 518 & 534 & 563 & 2119 \\
\hline
\end{tabular}

Armenia in 1991), whichever occurs first. Countries that ceased to exist during the period in question (e.g., the German Democratic Republic, in 1990) or broke up (e.g., Czechoslovakia into Czech Republic and Slovakia, as of 1993) were added to the dataset. A total of $(\mathrm{N}=)$ 147 countries under these conditions were identified.

The main independent variable of this paper, PHYSINT, was developed by Cingranelli and Richards (2005). It represents the index of governmental respect for the physical integrity of the population in a specific country and measures torture, extra-judicial deaths, political arrests, and disappearances. Our data were elaborated based on the annual reports of 'US Department country reports on human rights practices' and the 'Amnesty international'.

PHYSINT is an essential variable, as it indicates the level of governmental repression performed by official forces or noncommissioned officers and paramilitary groups. These data do not refer to state policy, but to actions effectively taken. It does not deal with human rights violation committed by third parties such as warlords, local gangs, and rebel groups. This index ranges from between 0 (total government violation of civil rights) to 8 (total government respect for civil rights).

The variable POLITY measures the level of democracy and hence the type of regime. The respective scale is shown below:

-10 to -6 Autocratic Regimes

-5 to 5 Hybrid Regimes

6 to 10 Democratic Regimes

Note that this paper combines two scales, varying between -10 (maximum autocracy) to +10 (maximum democracy).

The numeric scale takes into consideration three fundamental aspects: presence of institutions and procedures by means of which citizens may express their preferences towards candidates (existence or non-existence of competitive elections), institutional limitations to the power of the government Executive body, assurance of civil freedom for all citizens and political participation (Marshall and Jaggers, 2003).

The two independent variables (PR and CL) that follow were obtained from the Freedom House (Gastil, 2003) dataset. PR measures Citizens political rights in each country. The numeric classification varies from 1 to 7 ( 1 for countries that confer more political rights 
and 7 for those who limit basic political rights). The data were elaborated based on surveys of people's opinions about electoral processes, political participation, and the performance of the governments in their countries.

CL measures citizens' civil liberties. It varies from 1 to 7 (1 represents countries which grant high levels of civil rights to its citizens and 7 represents governments that restrict civil rights). Surveyors conducted interviews on issues such as freedom of expression, freedom of beliefs, right to associate, the rule of the law, personal autonomy and individual rights.

GDPEN is the only economic variable. It represents average income per capita by country/ year. The GDPEN was based on the WDI 2001 (of the World Bank), PWT 5.6 and the figures on energy consumption of the COW (Fearon and Laitin, 2001). It is largely used by researchers as a control variable.

The random-effect analysis is the most appropriated method used because some of those independent variables of interest (almost) don't vary through the years 1981-1997. Furthermore, the random-effect analysis was chosen because (a) it captures the variation by countries rather than variations within countries, for all the period in the case of fixedeffect. The random-effects are used when the difference between the period (in this case, number of years) and the number of countries is low. We have 17 years (or less, for countries that became independent after 1981 and/or disappeared before 1997) and 147 countries (with 2,234 observations), where the period is more than 8.5 times lower than the number of countries; (b) the dependent variable (civil war onset $=1$ ) is very rare when compared with countries free of civil war $(=0)$ and therefore a significant number of observations are eliminated when fixed-effect analysis' regression is used.

To facilitate the interpretation of results, odds ratio (OR) was adopted instead of the regular coefficient in the regression, to measure the direction and the power of each variable and not only its significance. The OR indicates that the risk of civil war onset relates to the risk of reference 1 . Therefore, if $\mathrm{OR}=1$, the $\mathrm{OR}$ does not have effect in the risk of reference (baseline). If $\mathrm{OR}=3$, the risk of a civil war breaking out is three times as high, and if $\mathrm{OR}$ $=0.5$, it is reduced by half. Significance was arranged into three groups: $\left.\mathrm{p} \leq 0.1{ }^{*}\right), \mathrm{p} \leq 0.5$ $\left.{ }^{* *}\right)$, and $\left.\mathrm{p} \leq 0.01{ }^{* * *}\right)$.

A problematic concept often used in the literature is anocracy, characterized by a mix of autocratic and democratic elements. This term is based on data rather than a robust theory. Gandhi and Vreeland (2004) disapproved of using the variable anocracy. The authors found that the risk of civil war is reduced in dictatorships with nominally democratic institutions (like the legislative power) as compared to other regimes.

However, they only investigated this specific kind of 'anocratic regime' (dictatorship with legislative power), and not all possible combinations of this category (Gandhi and Vreeland, 1004: 14). The reason for a reduced possibility of a civil war under this type of regime is that both the members of the government and opposition can express their differences and negotiate political commitments. The authors' statement is based on the difference between their findings in relation to those of other researchers especially because of the 
tools normally used by them to measure the regime(s) studied. They admit that "the difference is because [they have] used the Polity, and [their] work should not be taken as an indictment of previous work on civil war" (Gandhi and Vreeland, 2004: 19).

Many researchers use dichotomous datasets to refer to political regimes (e.g., Przeworski et al., 2000). As the purpose of this study is to work with a third type of political regime -or even with hybrid regimes, the possible but perhaps not ideal solution to us was to use the Polity dataset (Marshall and Jaggers, 2003), as it is a reference to researchers of this field. In this paper, the term anocracy was replaced by hybrid regime, which lies between the two political extremes- autocracy and democracy ( -5 to 5 in the scale -10 to 10 ).

\section{LOGISTIC REGRESSION ANALYSIS}

Table 1: Civil war onset and respect for human rights $\psi$.

\begin{tabular}{lccc}
\hline & $(1)$ & $(2)$ & $(3)$ \\
\hline & onset & onset & onset \\
PHYSICAL INTEGRITY & $0.815^{* * *}$ & $0.808^{* * *}$ & $0.822^{* *}$ \\
[PHYSINT] & $(0.064)$ & $(0.064)$ & $(0.070)$ \\
POLITICAL RIGHTS & & & $0.695^{*}$ \\
[PR] & & & $(0.140)$ \\
CIVIL LIBERTIES & & & 1.429 \\
[CL] & $2.926^{* * *}$ & & $(0.371)$ \\
HYBRID REGIMES & $(1.024)$ & & $2.988^{* * *}$ \\
[INTERPOL] & & & $(1.063)$ \\
DEMOCRATIC REGIMES & & $0.425^{*}$ & \\
[DEMOPOL] & & $(0.206)$ & \\
AUTOCRATIC REGIMES & & $0.306^{* * * *}$ & \\
[AUTOPOL] & & $(0.121)$ & \\
INCOME PER CAPITA & $0.565^{* * *}$ & $0.541^{* * * *}$ & $0.518^{* * *}$ \\
[GDPEN] & $(0.109)$ & $(0.112)$ & $(0.113)$ \\
\hline Number of observations (country-year) & 2,003 & 2,003 & $\mathbf{2 , 0 0 3}$ \\
Number of groups (countries) & 139 & 139 & $\mathbf{1 3 9}$ \\
Observations by group (from - until) & $1-17$ & $1-17$ & $\mathbf{1 - 1 7}$ \\
Hosmer-Lemeshow test (p =) & 0,139 & 0,022 & $\mathbf{0 , 7 8 4}$ \\
(goodness-of-fit) & & & \\
\hline
\end{tabular}

Source: Self made.

${ }^{\psi}$ Random-effects logistic regression performed by Intercooled Stata 8.2.

Significance: ${ }^{*} \mathrm{p} \leq 0.1{ }^{* *} \mathrm{p} \leq 0.05 ;{ }^{* * *} \mathrm{p} \leq 0.01$. Odds ratio (instead of coefficients) are presented. Standard errors are in parentheses. $\mathrm{N}=2,234$ observations (of 147 countries), for 1981-1997. 


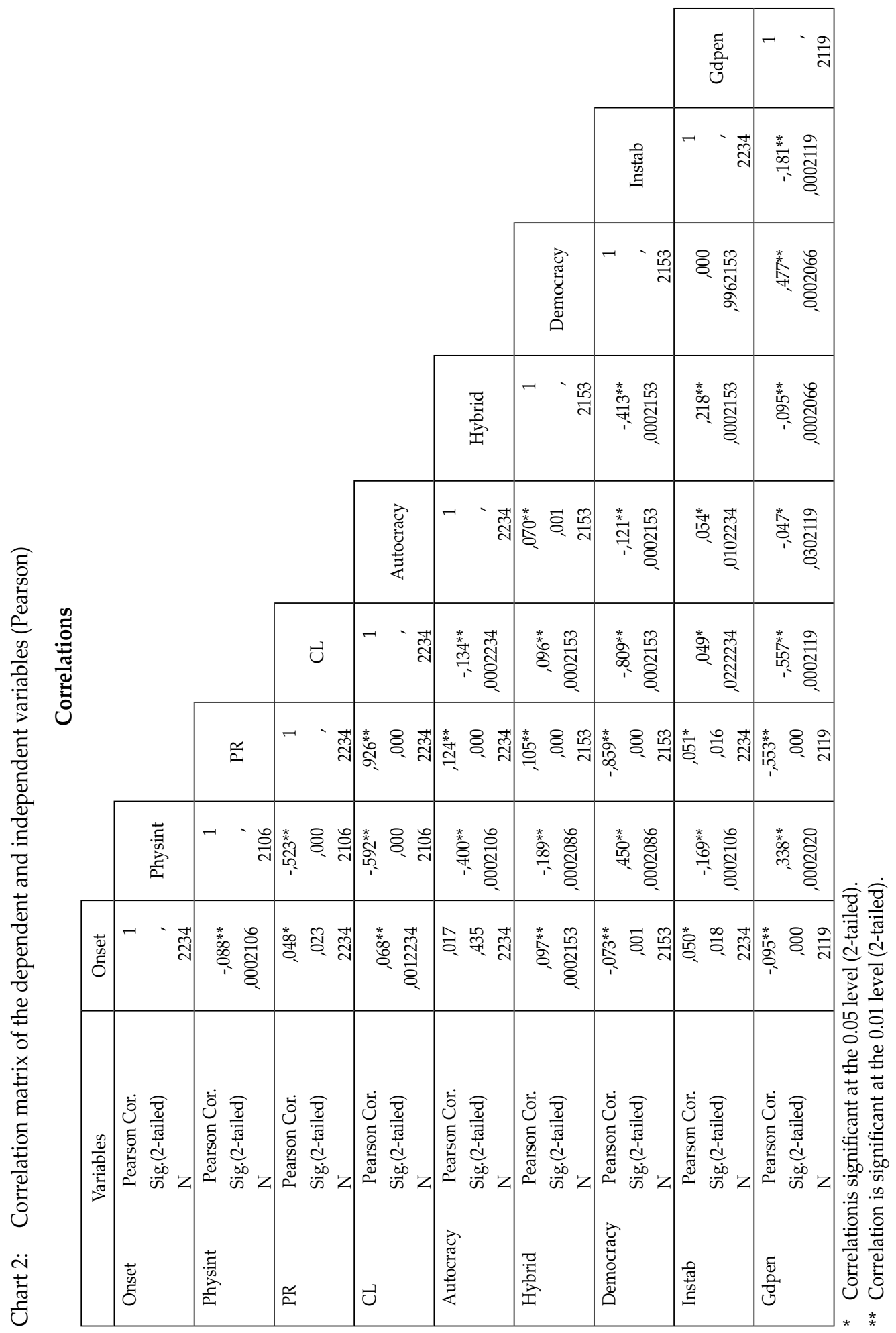




\section{RESULTS}

Hybrid regimes validated hypothesis 1 where the risk of a civil war breaking out is about three times as high as that under each type of regime added to the model. Government respect for physical integrity rights reduced the chances of a civil war breaking out by 0.8 times.

The presence of democratic and autocratic regimes reduces the risk of civil war (by 0.4 and 0.3 , respectively) in accordance with hypothesis 2 .

Finally, more political rights reduce the risk of civil war onset (about 0.7 ); even if the civil liberties are not significant in the models (hypothesis 2).

Every additional unit of average income per capita lowers the risk of civil war onset by almost 0.5 (half), confirming that rich countries have reduced risk for the outbreak of civil war, as shown in hypothesis 3 .

The data (number of observations) used in the three models included in table 1 are similar. Out of the 2,234 observations available in the dataset (231 observations $-10 \%$ - of the total are missing), 2,003 of each model are taken into account. Out of the 147 countries studied, 139 were considered in the analysis, and 1-17 country-year was analyzed for each model. The only difference between models is the results of the Hosmer \& Lemeshow (HL) test, which jointly assesses all independent variables in one model measuring the goodness of fit. Model 3 exhibits best performance for the entire model (0.784) compared to the other two models. Models 1 and 2 are very fragile ( 0.139 and 0.022 respectively), and cannot considered as good models. Even when CL is not significant, it can still be used as a control variable to improve the HL test (in the absence of CL, the HL test would drop to $\mathrm{p}=0.115$, a very low score).

In an attempt to obtain better results, quadratic transformations were made on the variables representing political regimes. However, no significant difference was ascertained. Therefore, we choose not to include this change on the variables that depict political regimes.

\section{VIII.CONCLUSION}

All hypotheses were tested and confirmed. The only non-significant variable tested was 'Civil liberties' (CL). All the theories used express the relevance of civil liberties for the civil war onset. Probably, the non-significance of this variable is given to technical reasons of how it is measured and not substantial ones. But CL is a control variable and cannot be extracted from the proposed equation (with the chance of reducing the HL test and make the whole model inoperative). Therefore, additional efforts should be made to surpass this obstacle. Thus, highly repressive hybrid regimes increase the likelihood of a civil war breaking out, whereas this risk is reduced in democratic and authoritarian regimes. Political rights granted by governments reduce the possibility of civil wars. Also, civil wars are much less likely to occur in rich countries than in poor ones. 
The sole analysis of political regime types is not sufficient to predict civil war in a specific country. It is also necessary to associate the political regime with the repression levels the state imposes on its citizens, political rights and average income in order to predict the outbreak of civil wars. As shown in this paper, the literature on failed states does not address this issue from our perspective, which is essential to the understanding of this specific subject.

Implementing a democracy in non-democratic states might be positive in the long run -but in the mid-term, if combined with repression by the government and low average per capita income, it increases the risk of a civil war. This has been empirically confirmed by the current American experiences in Iraq and Afghanistan. Nevertheless, there are much more complex elements to it, and those specific events cannot be explained based solely on the political regime variable.

Civil disobedience/obedience should be related to a regime's level of legitimacy accredited by citizens. If they feel the regime is against them and all other institutional measures to change a specific situation are exhausted, then the only possibility to fight the state is through a civil war. Civil wars are scarce and they only occur when the subjects have the moral right to rebel against the political authority in an exceptional circumstance. If the regime is of a hybrid type and government repression is high, the risk of civil war breaking out is increased, as confirmed by the empirical results.

Autocracy might prevent a civil war because citizens fear being punished by the state. However, in hybrid regimes states are unskilled to effectively repress demonstrations. In democracies, in turn, states have the means to repress, but they do not need to do so, as citizens can lawfully perform open pacific manifestations, which has been observed in consolidated -and not so young-democracies.

Finally, the civil war quantitative literature should be backed by more robust theory, and it's one of the main objectives of the present work. At the beginning of this paper, we get the political philosophy assistance, but this subject is multidisciplinary and scholars could be aided by other theoretical fields as well. The importance, in our view, is to complement the rich data and statistical tools disposable to the academy by a good theoretical argumentation, making the empirical work sustainable. 


\section{REFERENCES}

Boix, Carles. 2004. "Political violence". In Order, Conflict and Violence: Conference Papers, edited by Yale University. New Haven (II): Yale University, 5-59.

Brockett, Charles. 1991. "The Structure of Political Opportunities and Peasant Mobilization in Central America". Comparative politics 23(3): 253-274.

Cingranelli, David and David Richards. 2005. The Cingranelli-Richards (CIRI) Human Rights Dataset. [On line] <http:/ /www.humanrightsdata.com> [October 28, 2007].

1999. “Measuring the Level, Pattern, and Sequence of Government Respect for Physical Integrity Rights". International studies quarterly 43(2): 407-18.

Collier, Paul. et alli. 2003. Breaking the Conflict Trap: Civil War and Development Policy. Washington DC: World Bank \& Oxford University Press.

Doyle, Michael and Nicholas Sambanis. 2000. "International Peacebuilding: A Theoretical and Quantitative Analysis". American Political Science Review 94(4): 779-801.

Dworkin, Ronald. 1977. Taking Rights Seriously. Cambridge: Harvard University Press. 1985. "Civil Disobedience and Nuclear Protest". In A matter of principle, edited by R. Dworkin. Cambridge: Harvard University Press, 104-116. 1986. Law's Empire. Cambridge: Harvard University Press.

Fearon, James and David Laitin. 2003. "Additional Tables for Ethnicity, Insurgency, and Civil War". Department of Political Science, Stanford University.

2003. "Ethnicity, Insurgency, and Civil War". The American Political Science Review 97(1): 75-90.

1999 "Weak States, Rough Terrain, and Large-Scale Ethnic Violence Since 1945". Non-publicized manuscript. Stanford, CA. [On line] <http://www.stanford.edu/group/ethnic/workingpapers/ insurg1.pdf> [October 28, 2007].

Gandhi, Jennifer and James Vreeland. 2004. "Political Institutions and Civil War: Unpacking Anocracy". Workshop on Order, Conflict and Violence. New Haven: Yale University.

Gastil, Raymond. 2003. Freedom House. In http:/ / www.freedomhouse.org

Gleditsch, Nils Petter et al. 2002. "Armed Conflict 1946-2001: A New Dataset". Journal of Peace Research 39(5): 615-637. [On line] <http:/ / www.prio.no/cwp/ArmedConflict> [October 28, 2007].

Hegre, Havard et al. 2001. "Toward a Democratic Civil Peace? Democracy, Political Change, and Civil War 1816-1992". American Political Science Review 95(1): 33-48.

Klosko, George. 1992. The Principle of Fairness and Political Obligation. Lanham: Rowman \& Littlefield.

Lyons, David. 1998. "Moral Judgment, Historical Reality, and Civil Disobedience". Philosophy \& Public Affairs v. XXVII (1): 31-49.

Marshall, Monty and Keith Jaggers. 2003. Political Regime Characteristics and Transitions, 1800-2004. CIDCM. University of Maryland. [On line] <http://www.cidcm.umd.edu/inscr/polity> [October 28, 2007].

Mason, David. 1998. "Take Two Acres and Call me in the Morning: Is Land Reform a Prescription to Peasant Unrest?". The Journal of Politics. 60(1): 199-230.

Montalvo, Jose and Marta Reynal-Querrol. 2005. "Ethnic Diversity and Economic Development". Journal of Development Economics 76(issue 2): 293-323.

Murphy, Mark. 1997. "Surrender of Judgment and the Consent Theory of Political Authority". Law and Philosophy 16(2): 115-143.

Pitkin, Hanna. 1965. “Obligation and Consent - I". American Political Science Review LIX (4): 990-999.

Prosterman, Roy. 1976. "IRI: a Simplified Predictive Index of Rural Instability". Comparative Politics 8(3): Special Issue on Peasants and Revolution, 339-353.

Przeworski, Adam et al. 2000. Democracy and Development. Cambridge: Cambridge University Press.

Rawls, John. 1999 (1964). "Legal Obligations and the Duty of Fair Play". In John Rawls: Collected Papers, edited by S. Freeman. Cambridge: Harvard University Press, 117-129. 1971. A Theory of Justice. Cambridge: Harvard University Press. 
Reynal-Querrol, Marta. 2002. "Ethnicity, Political Systems and Civil Wars". Journal of Conflict Resolution 46(1): 29-54.

Rummel, Rudolph. 1997. "Is Collective Violence Correlated with Social Pluralism?" Journal of Peace Research 34 (2): 163-175.

Sambanis, Nicholas. 2001. "Do Ethnic and Non-Ethnic Civil Wars Have the Same Causes? A Theoretical and Empirical Enquiry (Part 1)". Journal of Conflict Resolution 45(3): 259-282.

Sarkees, Meredith Reid. 2000. "The Correlates of War Data on War: An Update to 1997". Conflict Management and Peace Science 18(1): 123-144.

Scott, James. 1976. The Moral Economy of the Peasant: Rebellion and Subsistence in Southeast Asia. New Haven: Yale University Press.

Waldron, Jeremy. 1993. "Special Ties and Natural Duties". Philosophy and Public Affairs 22(1): 3-30.

The American Heritage Dictionary of the English Language. 2000. Published by Houghton Mifflin Company: Forth edition.

Artur Zimerman Masters degree in Social Science by The Hebrew University of Jerusalem (1999) and PhD. in Political Science by the Universidade de São Paulo (2006) about the agrarian determinants of civil wars worldwide, empirically. Presently, he is a post-doc researcher at Universidade de São Paulo on agrarian violence within Brazil. His area of study is violence, civil wars and agrarian issues in a quantitative approach.

(e-mail: artur@usp.br)

Hélio Ricardo do Couto Alves Masters degree in Political Science by the Universidade Federal do Rio Grande do Sul (2001) and PhD. in Political Science as well, by the Universidade de São Paulo (2006) about civil disobedience in a theoretical perspective. He is assistant professor at Fundação Universidade Federal do Rio Grande (FURG). His specialization is on contractarianism, rational choice theory and normative political theory.

(e-mail: hrca@uol.com.br) 
